\title{
Measurement of National Innovation Driving Force and Its Promotion of High-Quality Development of Service Industry
}

\author{
Jiang Wang, Jing $\mathrm{Ma}^{*}$ \\ School of Economics and Management, Beijing University of Technology, Beijing 100124, China
}

Corresponding Author Email: majing@emails.bjut.edu.cn

https://doi.org/10.18280/ijsdp.150710

Received: 8 April 2020

Accepted: 25 September 2020

\section{Keywords:}

national innovation driving force (NIDF), trade in services, institutional innovation, vertical and horizontal dispersion (VHD) method

\section{INTRODUCTION}

Science and technology (S\&T) have become the main driver of economic and social development. Countries around the world are competing to unleash the innovation driving force of innovation. From the strategy of building an innovative country in 2006 to the in-depth implementation of innovationdriven development in 2019, China has been sticking to innovation-led development, and pursuing both S\&T innovation and institutional innovation. Thanks to these efforts, China's innovation index ranking has risen for four consecutive years, reaching the 14th in the world in 2019. In the meantime, the trade in services in China has burgeoned. But there are still some problems, such as the irrational internal structure, the large gap from the global average proportion of trade in services, and insufficient opening of the service industry. Against this backdrop, this paper attempts to verify whether the service industry can achieve high-quality development (HQD) under the innovation driving force.

The relevant literature mainly tackles two issues: the measurement of the innovation driving force, and the influence of innovation. On the former issue, when the theory of national innovation system has not emerged, innovation was often characterized with a single S\&T innovation index, namely, enterprise investment in research and development (R\&D) [1], turnover of technology market [2], and the number of patents obtained by enterprise [3]. With the development of new institutional economics (NIE), institutional innovation indices like the national intellectual property protection capability [4], and Worldwide Governance Indicators (WGI) were introduced to measure innovation [5]. The theory on national innovation system highlights the importance to speed up the establishment of a national innovation system under state intervention [6]. As a result, innovation has gradually developed into a system.

Currently, countries have measured innovation systems differently. Chinese Academy of Science and Technology for Development created a national innovation index system with five primary indices, such as innovation resource, and knowledge creation. Cornell University, Institut Européen d'Administration des Affaires (INSEAD), and the World Intellectual Property Organization (a specialized agencies of the United Nations (UN)), jointly released the Global Innovation Index (GII), which consists of five inputs (e.g. human capital and research) and two outputs. In 2018, the European Union issued the European Innovation Scoreboard 2018 [7]. This innovation performance evaluation system covers four factors (e.g. investments, and innovation activities) and ten dimensions (e.g. human resources, and intellectual assets). The above research measures the innovation index from different perspectives, but does not reveal the internal structure of the innovation driving force, that is, does not strictly distinguish between the two components of innovation (S\&T innovation and institutional innovation). Therefore, their measuring tools cannot be directly applied to research the innovation driving force [8].

On the influence of innovation, the relevant studies mainly focus on the impact of innovation on products, industrial upgrading $[9,10]$, the quality and mode of economic growth and the formation of value chain [11-14]. The quality of economic growth is mostly measured by total factor productivity $[15,16]$. Overall, most scholars have emphasized on manufacturing, and empirically analyzed the influence of innovation from the angles of industry [17], and manufacturing products [18]. There is little report on the influence of innovation on the service industry. In addition, the metrics of innovation mainly concentrate on S\&T innovation. Few have explored how innovation affects economic growth. 
Therefore, this paper attempts to explore the scientific system of national innovation driving force (NIDF), and build an index system to measure the innovation driving force, making up for the defects of the existing innovation indices in explaining the connotations of innovation-driven development strategy. In addition, the research on innovation influence was extended to the service industry. From the perspective of domestic value-added ratio (DVAR) of export [19], the authors discussed the role of the innovation driving force on the HQD of the trade in services, aiming to provide new evidence to how innovation affects the overall economic quality.

The remainder of this paper is organized as follows: Section 2 sets up an index system to measure the innovation driving force, measures the NIDFs of samples, and comparatively analyzes the innovation driving force; Section 3 tests the influence of innovation driving force on the export DVAR of trade in services, and examines the relationship between the two factors through benchmark regression and heterogeneity analysis; Section 4 puts forward the conclusions.

\section{METHODOLOGY}

China aims to drive development through both S\&T innovation and institutional innovation. Drawing on the New Growth Theory [20], the NIE [21], and the National Innovation System (NIS) Theory [6, 22, 23], this paper constructs an NIDF index system with two primary indices (i.e. S\&T innovation and institutional innovation). Each primary index is supported by 3 secondary indices and 15 tertiary indices (Table 1).

Table 1. The NIDF index system

\begin{tabular}{|c|c|c|c|c|}
\hline$(1)$ & $(2)$ & (3) & $(4)$ & $(5)$ \\
\hline \multirow[t]{7}{*}{ I Indices } & \multirow[t]{3}{*}{ II Indices } & III Indices & $\begin{array}{c}\text { VHD } \\
\text { Weight }\end{array}$ & Data Source \\
\hline & & 1.1 Intensity of $R \& D$ expenditure input & 0.0351 & \\
\hline & & 1.2 Intensity of $R \& D$ manpower input & 0.0356 & WB \\
\hline & \multirow[t]{5}{*}{ Innovation Resources } & 1.3 The training level of scientific and technological human resources & 0.0322 & \\
\hline & & 1.4 Development level of informatization & 0.0360 & OECD \\
\hline & & 1.5 Proportion of R\&D in the world & 0.0287 & WB \\
\hline & & 2.1 Million of $R \& D$ expenditure scientific papers & 0.0261 & OECD; \\
\hline \multirow{14}{*}{$\begin{array}{c}\text { S\&T } \\
\text { Innovation }\end{array}$} & & 2.2 The number of scientific papers published by 10,000 researchers & 0.0308 & SCI \\
\hline & \multirow[t]{4}{*}{ Scientific Research } & 2.3 Proportion of valid patents in the world & 0.0288 & \\
\hline & & 2.4 Number of invention patent applications of million people & 0.0307 & \\
\hline & & 2.5 million us dollars economic output invention patent license & 0.0294 & WIPU \\
\hline & & 3.1 The proportion of tripartite patents in the world & 0.0290 & \\
\hline & \multirow{6}{*}{$\begin{array}{l}\text { Technological } \\
\text { Innovation }\end{array}$} & 3.2 Ratio of enterprise R\&D expenditure and added value & 0.0345 & OECD \\
\hline & & 3.3 PCT patent applications by 10,000 corporate researchers & 0.0316 & WIPO; \\
\hline & & 3.4 Comprehensive technical autonomy rate & 0.0322 & OECD \\
\hline & & 3.5 Enterprise researchers account for the proportion of all researchers & 0.0300 & OECD \\
\hline & & 4.1 Intensity of intellectual property protection & 0.0372 & \\
\hline & & 4.2 Status of local research and training professional services & 0.0367 & \multirow{14}{*}{ WEF } \\
\hline & \multirow{4}{*}{$\begin{array}{l}\text { S\&T } \\
\text { System }\end{array}$} & $\begin{array}{l}\text { 4.3 Degree of cooperation between enterprises and universities in research and } \\
\text { development }\end{array}$ & 0.0368 & \\
\hline & & 4.4 Availability of the latest technology & 0.0376 & \\
\hline & & 4.5 Foreign direct investment and technology transfer & 0.0332 & \\
\hline Institutional & & $\begin{array}{l}\text { 5.1 How easy it is for enterprise innovation projects to obtain venture capital } \\
\text { support }\end{array}$ & 0.0352 & \\
\hline \multirow{9}{*}{ Innovation } & \multirow{6}{*}{ Financial Support } & 5.2 Enterprises can easily obtain loans & 0.0347 & \\
\hline & & 5.3 Financing through the local stock market & 0.0358 & \\
\hline & & 5.4 Investor protection intensity & 0.0322 & \\
\hline & & 5.5 Degree of financial market development & 0.0360 & \\
\hline & & 6.1 The impact of government regulations on enterprise burden & 0.0338 & \\
\hline & & 6.2 Macroeconomic environment & 0.0333 & \\
\hline & \multirow[t]{3}{*}{ Policy Innovation } & 6.3 Effects of anti-monopoly policies & 0.0369 & \\
\hline & & 6.4 Technological innovation in government procurement & 0.0354 & \\
\hline & & 6.5 Availability of national scientists and engineers & 0.0346 & \\
\hline
\end{tabular}

\subsection{Index selection}

\subsubsection{Indices of S\&T innovation}

The goal of China's innovation-led development strategy can be decomposed into improving the capability of independent innovation, building an enterprise-based, marketoriented S\&T innovation system that integrates industry, university with research, and expediting the renovation of the S\&T system.

To improve the capability of independent innovation, the prerequisite is to gather an abidance of innovation resources; To build the said S\&T innovation system, the universities, enterprises, R\&D institutions, and the government must perform their own duties and actively cooperate with each other. Therefore, three secondary indices were selected for S\&T innovation: innovation resources, scientific research, and technological innovation.

\subsubsection{Indices of institutional innovation}

As mentioned above, the third dimension of the goal of China's innovation-led development strategy is to expedite the renovation of the S\&T system. Hence, both hard innovation (S\&T innovation) and soft innovation (institutional innovation) should be considered in the study of NIDF system. This paper attaches equal importance to S\&T innovation and institutional innovation. Three secondary indices were arranged for 
institutional innovation: S\&T system, financial support, and policy innovation.

\subsection{Construction of NIDF system}

The indices were preprocessed in two steps: normalization and weighting. The weighting was implemented through vertical and horizontal dispersion (VHD) method and principal component analysis (PCA), producing the innovation driving force scores of 32 sample countries in 2006-2014.

\section{Step 1. Normalization}

The 30 tertiary indices were normalized to eliminate their difference in unit of measurement. First, each tertiary index was normalized dynamically. Next, the cumulative probability for each normalized value to obey standard normal distribution was calculated, and multiplied with 100 into a processed value in the interval of $0-100$. The normalization process can be described as:

$$
Y_{i t}^{m}=100 \times \Phi\left(\frac{y_{i t}^{m}-\overline{y^{m}}}{s^{m}}\right)
$$

where, $Y_{i t}^{m}$ is the normalized value of $y_{i t}^{m} ; y_{i t}^{m}$ is the original value of index $m$ of country $i$ in year $t ; \bar{y}^{m}$ is the mean value of the 32 countries in the sample period; $s^{m}$ is the standard deviation; $\Phi(\mathrm{y})$ is the cumulative probability for $\mathrm{y}$ to obey standard normal distribution.

\section{Step 2. Weighting}

The indices were weighted firstly by the VHD method. This is an objective weighting method based on vertical and horizontal data sequences. The VHD method can reflect the sample difference in space, and also demonstrate the dynamic evolution over time. Based on the research data, a vertical and horizontal data table was established (Table 2).

Table 2. The vertical and horizontal data table

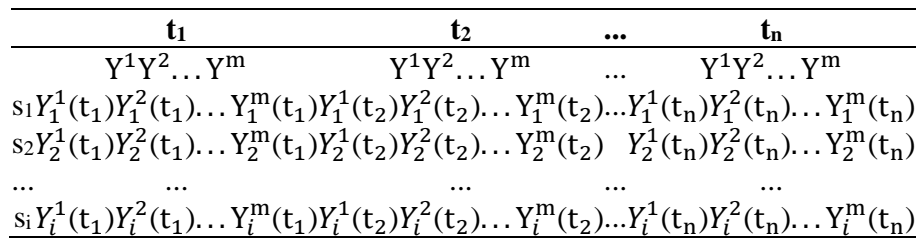

In Table 2, the horizontal data and vertical data stand for the data of various indices at a certain time and at different times, respectively; $Y_{i}^{m}\left(\mathrm{t}_{\mathrm{n}}\right)$ is the normalized value of index $\mathrm{m}$ of country $i$ at time $t_{n}(i=1,2, \ldots, 32 ; m=1,2, \ldots, 30 ; t=1,2, \ldots, 9)$.

During the process of the VHD method, the comprehensive evaluation function was determined as $M_{i}\left(t_{n}\right)=\sum_{m} \omega^{m} Y_{i}^{m}\left(t_{n}\right)$, where $\omega^{\mathrm{m}}$ is the weight of index $\mathrm{m}$, i.e. the weight to be calculated. The basic principle of the VHD method is to disperse the sample data both horizontally and vertically through weight assignment. In the comprehensive evaluation function, the overall difference between samples in vertical and horizontal data is expressed as the total sum of squares (TSS) of $\mathrm{M}_{\mathrm{i}}\left(\mathrm{t}_{\mathrm{n}}\right)$ :

$$
\sigma^{2}=\sum_{t=1}^{n} \sum_{i=1}^{p}\left(M_{i}\left(t_{n}\right)-\bar{M}\right)^{2}=\omega^{T} \sum_{t=1}^{n} H_{t} \omega=\omega^{T} H \omega
$$

where, $\omega=\left(\omega^{1}, \omega^{2}, \ldots, \omega^{\mathrm{m}}\right)^{\mathrm{T}} ; \mathrm{H}=\sum_{\mathrm{t}=1}^{\mathrm{n}} \mathrm{H}_{\mathrm{t}}$ is a symmetric matrix of order $m \times m$. Let $H_{t}=A_{t}^{T} A_{t}(t=1,2, \ldots, n)$, where

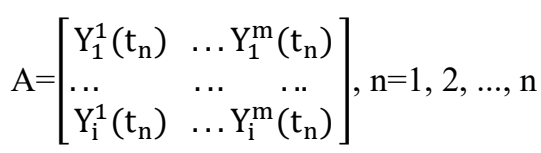

$A_{t}$ is a real symmetric matrix. It can be proved that, if $\omega^{\mathrm{T}} \omega=1$, and $\omega$ is the eigenvector corresponding to the maximum eigenvalue $\lambda_{\max }(H)$ of matrix $H$, then, $\sigma^{2}$ is maximized and $\max _{\|\omega=1\|} \omega^{\mathrm{T}} H \omega=\lambda_{\max }(H)$.

By the VHD method, the weights of the 30 tertiary indices were obtained (Column 4, Table 1). The weight of each primary and secondary index was calculated by adding up the weights layer by layer: inno ${ }_{i t}=\sum_{m} Y_{i}^{m} \times\left(\omega^{m} / \sum_{m} \omega^{m}\right)$. By totaling the relevant indices, the authors derived the national S\&T innovation index, the national institutional innovation index, and the NIDF index.

The PCA was also adopted for index weighting. Proposed by Hotelling in 1933, the PCA is a common multivariate statistical method. For the lack of space, the PCA weighting process is not detailed here. As shown in Table 3, the innovation driving forces measured by the two weighting methods were very close to each other, indicating that the PCA is a reasonable strategy and eligible for robustness testing.

\subsection{Cross-country comparison of NIDF}

Table 3 presents the NIDF scores of different countries in 2006-2014. Vertically, developed countries in Europe, America, and Japan occupied the top 10 seats, and boasted absolute advantages in NIDF. In both 2006 and 2014, the United States (US) ranked first, while Mexico stayed at the bottom. To a certain extent, the NIDF is unlikely to change significantly in a short time.

Horizontally, $31 \%$ of all countries witnessed NIDF improvement, and $44 \%$ climbed up in the NIDF ranking. China achieved the fastest growth: its ranking rose from the relatively low $28^{\text {th }}$ in 2006 to the $17^{\text {th }}$ in 2014 . Besides, China is the only developing country among the top 20 in the ranking. Whereas the innovation driving force declined in some countries, China increased its NIDF score by 14.64 points, and improved its ranking by 11 places. By contrast, South Korea experienced the fastest decline in innovation driving force. 
Table 3. The NIDF indices

\begin{tabular}{|c|c|c|c|c|c|c|c|c|c|c|}
\hline Country & $\begin{array}{c}\mathbf{v} \\
\mathbf{y} 2014 \text { NIDF } \\
\text { Indices } \\
\end{array}$ & $\begin{array}{l}\text { HD } \\
2014 \text { NIDF } \\
\text { Ranking } \\
\end{array}$ & $\begin{array}{r}\mathbf{P} \\
2014 \text { NIDF } \\
\text { Indices } \\
\end{array}$ & $\begin{array}{l}\text { CA } \\
2014 \text { NIDF } \\
\text { Ranking } \\
\end{array}$ & $\begin{array}{c}\mid \text { Index } \\
\text { Difference }\end{array}$ & $\begin{array}{c}\text { | Ranking } \\
\text { Difference | }\end{array}$ & $\begin{array}{l}2006 \text { NIDF } \\
\text { Indices }\end{array}$ & $\begin{array}{l}2006 \text { NIDF } \\
\text { Ranking }\end{array}$ & $\begin{array}{c}\mid \text { Index } \\
\text { Difference } \mid \\
(2006-2014)\end{array}$ & $\begin{array}{c}\text { Ranking } \\
\text { Difference| } \\
(\mathbf{2 0 0 6 - 2 0 1 4 )}\end{array}$ \\
\hline USA & 74.43 & 1 & 75.80 & 2 & 1.37 & 1 & 76.63 & 1 & -2.20 & 0 \\
\hline FIN & 72.78 & 2 & 73.32 & 3 & 0.54 & 1 & 74.79 & 3 & -2.01 & 1 \\
\hline SWE & 70.31 & 3 & 70.54 & 6 & 0.23 & 3 & 75.47 & 2 & -5.16 & -1 \\
\hline JPN & 70.24 & 4 & 77.09 & 1 & 6.85 & 3 & 73.69 & 5 & -3.45 & 1 \\
\hline GER & 69.44 & 5 & 72.19 & 5 & 2.75 & 0 & 68.85 & 7 & 0.59 & 2 \\
\hline NOR & 68.02 & 6 & 61.65 & 9 & 6.37 & 3 & 64.74 & 11 & 3.28 & 5 \\
\hline NED & 63.99 & 7 & 62.33 & 8 & 1.66 & 1 & 65.63 & 8 & -1.64 & 1 \\
\hline LUX & 62.69 & 8 & 58.18 & 12 & 4.51 & 4 & 52.42 & 15 & 10.27 & 7 \\
\hline DEN & 61.98 & 9 & 64.75 & 7 & 2.77 & 2 & 72.97 & 6 & -10.99 & -3 \\
\hline CAN & 61.44 & 10 & 55.43 & 15 & 6.01 & 5 & 64.87 & 10 & -3.43 & 0 \\
\hline GBR & 61.44 & 11 & 57.55 & 13 & 3.89 & 2 & 65.11 & 9 & -3.67 & -2 \\
\hline KOR & 61.28 & 12 & 72.41 & 4 & 11.13 & 8 & 74.47 & 4 & -13.19 & -8 \\
\hline FRA & 58.07 & 13 & 58.65 & 11 & 0.58 & 2 & 56.90 & 14 & 1.17 & 1 \\
\hline BEL & 56.53 & 14 & 56.47 & 14 & 0.06 & 0 & 58.65 & 13 & -2.12 & -1 \\
\hline AUT & 55.63 & 15 & 59.96 & 10 & 4.33 & 5 & 59.39 & 12 & -3.76 & -3 \\
\hline EST & 48.76 & 16 & 43.83 & 18 & 4.93 & 2 & 48.90 & 16 & -0.14 & 0 \\
\hline $\mathrm{CHN}$ & 45.87 & 17 & 50.82 & 16 & 4.95 & 1 & 31.23 & 28 & 14.64 & 11 \\
\hline $\mathrm{CZE}$ & 41.73 & 18 & 40.55 & 19 & 1.18 & 1 & 37.98 & 20 & 3.75 & 2 \\
\hline POR & 39.58 & 19 & 38.96 & 20 & 0.62 & 1 & 43.32 & 18 & -3.74 & -1 \\
\hline SLO & 38.38 & 20 & 46.37 & 17 & 7.99 & 3 & 42.00 & 19 & -3.62 & -1 \\
\hline ESP & 36.63 & 21 & 37.63 & 22 & 1.00 & 1 & 43.83 & 17 & -7.20 & -4 \\
\hline LTU & 36.03 & 22 & 33.70 & 24 & 2.33 & 2 & 35.02 & 21 & 1.01 & -1 \\
\hline TUR & 34.49 & 23 & 33.90 & 23 & 0.59 & 0 & 34.74 & 22 & -0.25 & -1 \\
\hline ITA & 32.80 & 24 & 37.81 & 21 & 5.01 & 3 & 32.99 & 26 & -0.19 & 2 \\
\hline LAT & 31.98 & 25 & 29.59 & 29 & 2.39 & 4 & 29.99 & 29 & 1.99 & 4 \\
\hline POL & 31.72 & 26 & 31.72 & 26 & 0.00 & 0 & 32.71 & 27 & -0.99 & 1 \\
\hline SVK & 30.08 & 27 & 27.63 & 30 & 2.45 & 3 & 34.53 & 23 & -4.45 & -4 \\
\hline RUS & 28.29 & 28 & 32.39 & 25 & 4.10 & 3 & 28.97 & 30 & -0.68 & 2 \\
\hline GRE & 27.69 & 29 & 30.13 & 27 & 2.44 & 2 & 33.26 & 25 & -5.57 & -4 \\
\hline ROU & 27.59 & 30 & 25.88 & 31 & 1.71 & 1 & 27.41 & 31 & 0.18 & 1 \\
\hline HUN & 27.21 & 31 & 29.86 & 28 & 2.65 & 3 & 34.02 & 24 & -6.81 & -7 \\
\hline MEX & 25.41 & 32 & 24.05 & 32 & 1.36 & 0 & 23.96 & 32 & 1.45 & 0 \\
\hline
\end{tabular}

\section{INFLUENCE OF INNOVATION ON EXPORT DVAR OF TRADE IN SERVICES}

\subsection{Measurement model}

To empirically analyze the influence of innovation driving force on the export competitiveness of trade in services, the equation between the two factors was established as:

$$
\operatorname{dvar}_{j i t}=\alpha+\beta_{1} \ln i n n o v_{i t}+\beta_{2} \ln X_{j i t}+\gamma_{j}+\delta_{i}+\mu_{t}+\varepsilon_{j i t}
$$

where, the subscript $\mathrm{j}$ is the serial number of the sector that carries out trade in services $j=1 \sim 10 ; i$ is the serial number of countries, $i=1 \sim 32$; $t$ is the year, $t=1 \sim 9$ (the sample period was set to 2006-2014, due to the data availability of export DVAR of trade in services); explained variable $d v a r_{j i t}$ is the export DVAR of sector $j$ in country $i$ at year $t$; explanatory variable $\ln _{\text {inno }} v_{i t}$ is the NIDF index weighted by the VHD method (NIDF index and its two primary indices are taken for regression); $\ln X_{j i t}$ is the logarithm of control variable; $\gamma_{j}, \delta_{i}$ and $\mu_{t}$ are the control variables of secotr, country, and year, respectively.

\subsection{Data sources}

The data of the explained variable $d v a r_{j i t}$ come from the World Input-Output Tables (WIOT) 2016, released by World Input-Output Database (WIOD). Since our object is the export
DVAR of trade in services, the 28 sectors C28-C56 in WIOT 2016 were divided into 10 service sectors, according to the Global Value Chain Index System of University of International Business and Economics. Then, the export DVAR of trade in services of each sample country was obtained by weighting the export DVAR of each sector in that country.

In benchmark regression, the explanatory variable $\ln$ innov $_{\text {it }}$ was regressed separately from the NIDF index, S\&T innovation index, and institutional innovation index, which were weighted by the VHD method.

The control variables $\ln X_{j i t}$ includes four sector-level control variables (i.e. export level, structure, productivity, and revealed comparative advantage) and three country-level control variables (i.e. per-capita gross domestic product (GDP), total population, and tax rate). The sector-level control variables were obtained from WIOT2016, while the countrylevel ones were acquired from the World Development Indicators released by the World Bank (WB).

\subsection{Benchmark regression}

After the Hausman Test for endogeneity, the fixed-effects model was selected for benchmark regression, with fixed effects of sector, country, and year. The results of benchmark regression are presented in Table 4.

Column 1 records the results of fixed-effects regression of innovation driving force without control variables. Columns 2 and 3 provides the results of fixed-effects regression with 
control variables, and the results of ordinary least squares (OLS) regression, respectively. Our expectation is that NIDF promotes the HQD of the trade in services. Thus, it is assumed that coefficient of innovation driving force $\beta_{1}>0$, i.e. the export DVAR of trade in services increases with NIDF index and its internal indices. In the above three regressions, the $\beta_{1}$ values were all significantly positive, indicating that stronger NIDF promotes the export DVAR of trade in services.

In Columns 4 and 5 , the explanatory variables are respectively the S\&T innovation index and the institutional innovation index, both are under the NIDF index. From the benchmark regression results, it can be seen that the coefficient $\beta_{1}$ of institutional innovation index was significantly positive, suggesting that the national institutional innovation capacity promotes the export DVAR of trade in services. This is in line with our expectation. Contrary to our expectation, the coefficient $\beta_{1}$ of S\&T innovation index was significantly negative. Hence, the promoting effect of innovation driving force on the export DVAR of trade in services stems from institutional innovation, rather than S\&T innovation.

Table 4. The results of benchmark regression and the regression with sector innovation intensity

\begin{tabular}{|c|c|c|c|c|c|c|c|c|}
\hline Variable & (1) & (2) & (3) & (4) & (5) & (6) & (7) & (8) \\
\hline & FE & $\mathrm{FE}$ & GLS & FE & FE & The Whole Group & $\begin{array}{c}\text { The } \\
\text { High Group }\end{array}$ & $\begin{array}{c}\text { The } \\
\text { Low Group }\end{array}$ \\
\hline $\begin{array}{l}\text { NIDF } \\
\text { Indices }\end{array}$ & $\begin{array}{c}0.022 * * \\
(2237)\end{array}$ & $\begin{array}{c}0.035 * * * \\
(4320)\end{array}$ & $0.031 * * *$ & & & & & \\
\hline $\begin{array}{c}\text { S\&T } \\
\text { Innovation }\end{array}$ & & & & $\begin{array}{c}-0.075 * * * \\
(-8.302)\end{array}$ & & & & \\
\hline $\begin{array}{l}\text { Institutional } \\
\text { Innovation }\end{array}$ & & & & & $\begin{array}{c}0.024 * * * \\
(6.928)\end{array}$ & & & \\
\hline NIDF $\times$ Complexity Indices & & & & & & $\begin{array}{c}0.010 \\
(1.570)\end{array}$ & $\begin{array}{c}0.018 * * \\
(1.978)\end{array}$ & $\begin{array}{c}0.002 \\
(0.217)\end{array}$ \\
\hline Control Variable & No & Yes & Yes & Yes & Yes & Yes & Yes & Yes \\
\hline Country, Industry, Year Fixed Effects & Yes & Yes & Yes & Yes & Yes & Yes & Yes & Yes \\
\hline No. of Observations & 2782 & 2444 & 2442 & 2444 & 2444 & 2880 & 1440 & 1440 \\
\hline
\end{tabular}

Note: The bracketed values are t-statistic; $* * *$ and $* *$ are $\mathrm{p}<0.01$ and $\mathrm{p}<0.05$, respectively. For the lack of space, only the main explanatory variables are reported here.

Table 5. The regression results of robustness test

\begin{tabular}{|c|c|c|c|c|c|c|}
\hline Variable & (1) & $(2)$ & (3) & (4) & (5) & (6) \\
\hline NIDF & $0.006 * * *$ & \multirow{2}{*}{\multicolumn{5}{|c|}{$\begin{array}{c}0.050 * * * \\
(4.570)\end{array}$}} \\
\hline Indices & $(3.367)$ & & & & & \\
\hline S\&T Innovation & \multicolumn{3}{|c|}{$\begin{array}{c}-0.045^{* * *} \\
(-6.813)\end{array}$} & \multicolumn{3}{|c|}{$\begin{array}{c}-0.087 * * * \\
(-8.935)\end{array}$} \\
\hline $\begin{array}{l}\text { Institutional } \\
\text { Innovation }\end{array}$ & & & $\begin{array}{r}0.023 * * \\
(6.826)\end{array}$ & & & $\begin{array}{c}0.031 * * * \\
(7.150)\end{array}$ \\
\hline Control Variable & Yes & Yes & Yes & Yes & Yes & Yes \\
\hline Country, Industry, Year Fixed Effects & Yes & Yes & Yes & Yes & Yes & Yes \\
\hline No. of Observations & 2444 & 2444 & 2444 & 2127 & 2127 & 2127 \\
\hline
\end{tabular}

Note: The bracketed values are t-statistic; *** and $* *$ are $\mathrm{p}<0.01$ and $\mathrm{p}<0.05$, respectively. For the lack of space, only the main explanatory variables are reported here.

\subsection{Robustness test}

\subsubsection{Test with weight adjustment}

The key variable of this research is the NIDF index. During the robustness test, the weights of the indices were assigned by the PCA. The regression results on the indices with PCA weights are listed in Columns 1-3, Table 5. It can be seen that the coefficients $\beta_{1}$ of NIDF index and its two primary indices had the same significance and direction (positive/negative) as those in benchmark regression. This means stronger NIDF can greatly elevate the export DVAR of trade in services.

\subsubsection{Test on endogeneity}

The above analysis assumes that the influence of innovation on export is unidirectional. In reality, international trade also has an impact on innovation. Thus, the above regression equations may have endogeneity. To solve the problem, the measurement model was modified by adding a single lag to the indices:

$$
\operatorname{dvar}_{j i t}=\alpha+\beta_{1} \ln \operatorname{innov}_{i t-1}+\beta_{2} \ln X_{j i t}+\gamma_{j}+\delta_{i}+\mu_{t}+\varepsilon_{j i t}
$$

The regression results of Eq. (5) are listed in Columns 4-6, Table 5. The lagged NIDF index and its two primary indices had the same significance and direction (positive/negative) as those in benchmark regression, and the absolute values of their coefficients $\beta_{1}$ were all larger than those in benchmark regression. These results demonstrate that the promoting effect of NIDF on the export DVAR of trade in services has a lagging effect.

\subsection{Test with sector innovation intensity}

\subsubsection{Index selection}

The benchmark regression does not explore the situation in different sectors. The following question remains to be answered: Does the influence of innovation driving force vary from sector to sector? Referring to the product complexity indices of Hausemann et al. (2007), the authors designed the sector innovation intensity index $\operatorname{inin}_{j t}$ :

$$
\operatorname{inin}_{j t}=\sum_{i} \frac{\left(\text { dvar }_{j i t} / \text { dvar }_{i t}\right)}{\sum_{i}\left(\text { dvar }_{j i t} / \text { dvar }_{i t}\right)} \times \text { inno }_{i t}
$$


where, dvar ${ }_{j i t}$ is the export DVAR of sector $\mathrm{j}$ in country $\mathrm{i}$ at year $t$; dvar ${ }_{i t}$ is the total export DVAR of 10 service sectors in country $i$ at year $t$; inin $_{j t}$ is the weighted average innovation capacity of sector $\mathrm{j}$ in 32 countries at year $\mathrm{t}$ (the weight is approximately the revealed comparative advantage of each country in sector $\mathrm{j}$.

The greater the proportion of dvar $_{\text {jit }}$ in dvar $_{\text {it }}$ of a country with a high level of innovation, the larger the $\operatorname{inin}_{j t}$, the more intense the innovation in sector $\mathrm{j}$, and the more dependent sector $\mathrm{j}$ is on a good innovation environment.

Based on the 9-year average innovation intensity, the 10 sectors were divided into a high innovation intensity group (R\&D, technological activities, other services, telecommunications, finance and insurance, and postal services) and a low innovation intensity group (retail trade, advertising and market research, management services, accommodation and catering, wholesale trade, and inland transport and storage).

\subsubsection{Model design}

Taking the NIDF index as the explanatory variable, the sector innovation intensity was introduced as the premise for the NIDF to influence the export DVAR of the service industry. Therefore, the measurement model was designed as:

$$
\operatorname{dvar}_{j i t}=\alpha_{0}+\beta_{1} \operatorname{lninin}_{j t} \cdot \text { inno }_{i t}+\ln X_{i t}+\gamma_{j}+\delta_{i}+\mu_{t}+\varepsilon_{j i t}
$$

where, the subscript $\mathrm{j}$ is the serial number of the 10 service sector, $\mathrm{j}=1 \sim 10$; $\mathrm{i}$ is the serial number of countries, $\mathrm{i}=1 \sim 32$; $t$ is the year, $\mathrm{t}=1 \sim 9$; explained variable $d v a r_{j i t}$ is the export DVAR of sector $\mathrm{j}$ in country $\mathrm{i}$ at year $\mathrm{t}$; inin $_{j t}$ is the innovation intensity of sector $\mathrm{j}$ at year $\mathrm{t}$; inno $_{i t}$ is the NIDF index of country $\mathrm{i}$ at year $\mathrm{t} ; X_{i t}$ is the six country-level control variables: per-capita GDP, total population, tax rate, international direct investment, service export, and trade openness.

Our research focuses on coefficient $\beta_{1}$ of $\operatorname{lninin}_{j t} \cdot$ inno $_{i t}$. For a specific sector, if $\beta_{1}>0$, then the export DVAR and export competitiveness in that sector increase with NIDF index; if $\beta_{1}<0$, then the export DVAR and export competitiveness in that sector decrease with the increase of NIDF index.

The data on the six country-level control variables were collected from the World Development Indicators released by the WB, and the United Nations Conference on Trade and Development (UNCTAD).

\subsubsection{Analysis on empirical results}

After adding the sector innovation intensity, the fixedeffects model was still selected for regression, with fixed effects of sector, country, and year. The regression results are displayed in Columns 6-8, Table 4, where Columns 6, 7, and 8 are the regression results on all samples, the high innovation intensity group, and the low innovation intensity group.

The regression results show that, for sectors with high innovation intensity, NIDF greatly elevated the export DVAR of trade in services; for sectors with low innovation intensity, NIDF did not greatly improve the export DVAR of trade in services. Hence, a high sector innovation intensity is the prerequisite for the NIDF index to promote the export DVAR of trade in services.

\section{CONCLUSIONS}

(1) The NIDF of a country is positively correlated with the level of economic development. From the innovation index ranking, the top ten in the sample period are all developed countries, while China is the leader among developing countries. Therefore, China must unswervingly pursue innovation-led development, and promote the collaborative development between S\&T and institutional innovations. Specifically, the government, enterprises, universities and research institutes should jointly build a collaborative innovation platform to allocate resources more efficiently; the intellectual property strategies and innovation benefit distribution mechanisms should match the level of economic development; incentive policies should be rolled out to optimize the innovation environment.

(2) The NIDF index of a country has a significant positive impact on its export DVAR of trade in services. The impact mainly comes from institutional innovation. Therefore, China should vigorously enhance institutional innovation, and better empower and reduce the burden for S\&T innovation by removing the institutional barriers. To attract high-quality foreign investment despite the challenge of COVID-19, China needs to further open up service sectors like telecommunications, finance, and the Internet, coordinate the implementation of foreign trade policies, and ensure the consistency of various policies on foreign investment.

(3) The NIDF has different influences on the export DVAR in different service sectors. For sectors with high innovation intensity, NIDF greatly elevated the export DVAR of trade in services; for sectors with low innovation intensity, NIDF did not greatly improve the export DVAR of trade in services. To realize the HQD of the service industry, China must identify the innovation demand of the industry, allocate innovation resources reasonably, and make good top-level design of institutional innovation: lay down more favorable policies on and divert more talents and resources to emerging innovationintensive sectors that focus on $\mathrm{R} \& \mathrm{D}$. The development of emerging trade in services will improve the transformation and upgrading of the trade structure.

\section{ACKNOWLEDGMENTS}

National Social Science Foundation Youth Project "Research on Internationalization Development Mode and Policy Choice of Independent Innovation System of Science and Technology Service Industry in China" (Grant No.: 14CGL003).

\section{REFERENCES}

[1] Cohen, W., Levinthal, D. (1989). Innovation and learning: The two faces of R \& D. The Economic Journal, 99(397): 569-596. https://doi.org/10.2307/2233763

[2] Shankar, K., Ghosh, S. (2013). A theory of worker turnover and knowledge transfer in high-technology industries. Journal of Human Capital, 7(2): 107-129. https://doi.org/10.1086/671188

[3] Yin, Z., Mao, H. (2017). 11. China's Patent Protection and Enterprise R\&D Expenditure. China's New Sources of Economic Growth, 245.

[4] Iwaisako, T. (2016). Effects of patent protection on optimal corporate income and consumption taxes in an R\&D-based growth model. Southern Economic Journal, 83(2): 590-608. https://doi.org/10.2307/26632355 
[5] Dasgupta, S., de Cian, E. (2016). Fondazione Eni Enrico Mattei (FEEM).

[6] Freeman, C. (1962). Research and development: A comparison between British and American industry. National Institute Economic Review, 21-39.

[7] Insead, W. (2018). Cornell University.(2018). The global innovation index. Energizing the World with Innovation.

[8] European, C. (2018). European Innovation Scoreboard [EB/OL].

[9] Ma, J., Guo, M. (2019). Technology innovation driven upgrade strategy evaluation model: A case of marine equipment industry. Journal of Coastal Research, 94(S1): 842-845. https://doi.org/10.2307/26854059

[10] Wu, Q., Wang, W. (2019). Environmental measurement and cluster analysis of manufacturing transformation and upgrading: An empirical study in eastern coastal cities in China. Journal of Coastal Research, 94(S1): 867-872. https://doi.org/10.2307/26854064

[11] Legros, D., Galia, F. (2012). Are innovation and R\&D the only sources of firms' knowledge that increase productivity? An empirical investigation of French manufacturing firms. Journal of Productivity Analysis, 38(2): 167-181. https://doi.org/10.1007/s11123-0110254-y

[12] Rice, C.F., Yayboke, E. (2017). Innovation-led economic growth: transforming tomorrow's developing economies through technology and innovation. Rowman \& Littlefield. https://doi.org/10.2307/resrep23182.10

[13] Feng, L., Li, Z., Swenson, D.L. (2016). The connection between imported intermediate inputs and exports: evidence from chinese firms. Journal of International Economics, 101: 86-101. https://doi.org/10.1016/j.jinteco.2016.03.004

[14] Elliott, R., Jabbour, L., Zhang, L. (2016). Firm productivity and importing: Evidence from Chinese manufacturing firms. The Canadian Journal of Economics/Revue Canadienne D'Economique, 49(3): 1086-1124. https://doi.org/10.1111/caje.12226

[15] Garnaut, R., Fang, C., Song, L., Johnston, L. (2016). China's new sources of economic growth: A supply-side perspective. China's New Sources of Economic Growth: Reform, Resources and Climate Change, 1-21.

[16] Peters, B., Roberts, M.J., Vuong, V.A., Fryges, H. (2017) Estimating dynamic R\&D choice: An analysis of costs and long-run benefits. The RAND Journal of Economics, 48(2): 409-437. https://doi.org/10.1111/17562171.12181

[17] Yang, L., Hou, G. (2019). Study on the strategic innovation and industrial development effect of marine industry. Journal of Coastal Research, 581-584. https://doi.org/10.2307/26854007

[18] Mason, C. (2017). Social enterprise in Australia: The need for a social innovation ecosystem. AQ: Australian Quarterly, 88(3): 25-44.

[19] Kee, H., Tang, H. (2016). Domestic value added in exports: theory and firm evidence from China. The American Economic Review, 106(6): 1402-1436. https://doi.org/10.1596/1813-9450-7491

[20] Romer, P. (1990). Endogenous technological change. Journal of Political Economy, 98(5): S71-S102. https://doi.org/10.1086/261725

[21] North, D.C. (2005). Understanding the Process of Economic Change. Princeton University Press.

[22] Nelson, R.R. (2005). Technology, institutions and economic growth. Forgn Affairs, 85(2).

[23] Hausmann, R., Hwang, J., Rodrik, D. (2007). What you export matters. Journal of Economic Growth, 12(1): 1-25. https://doi.org/10.1007\%2Fs10887-006-9009-4 